\title{
Ion-channel blocker sensitivity of voltage-gated calcium-channel homologue Cch1 in Saccharomyces cerevisiae
}

\begin{abstract}
Correspondence
Hidetoshi lida

iida@u-gakugei.ac.jp
\end{abstract}

Received 1 June 2008

Revised 27 July 2008

Accepted 25 August 2008
Jinfeng Teng, ${ }^{1,2} \dagger$ Rika Goto, ${ }^{1} \dagger$ Kazuko lida, ${ }^{3}$ Itaru Kojima ${ }^{2}$ and Hidetoshi lida ${ }^{1,4}$

\footnotetext{
${ }^{1}$ Department of Biology, Tokyo Gakugei University, 4-1-1 Nukui kita-machi, Koganei-shi, Tokyo 184-8501, Japan

${ }^{2}$ Laboratory of Cell Biology, Institute for Molecular and Cellular Regulation, Gunma University, Maebashi, Gunma 371-8510, Japan

${ }^{3}$ Biomembrane Signaling Project 2, Tokyo Metropolitan Institute of Medical Science, 3-18-22 Honkomagome, Bunkyo-ku, Tokyo 113-8613, Japan

${ }^{4}$ Department of Bioenvironmental Science, Okazaki Institute for Integrative Bioscience, National Institutes of Natural Sciences, Higashiyama 5-1, Myodaiji, Okazaki, Aichi 444-8787, Japan
}

The Cch1 protein of the yeast Saccharomyces cerevisiae is a homologue of the pore-forming $\alpha_{1}$ subunit of mammalian voltage-gated $\mathrm{Ca}^{2+}$ channels (VGCCs), and it constitutes a high-affinity $\mathrm{Ca}^{2+}$-influx system with the Mid1 protein in this organism. Here, we characterized the kinetic property of a putative Cch1-Mid1 $\mathrm{Ca}^{2+}$ channel overexpressed in S. cerevisiae cells, and showed that the L-type VGCC blockers nifedipine and verapamil partially inhibited Cch1-Mid1 activity, but typical P/Q-, N-, R- and T-type VGCC blockers did not inhibit activity. In contrast, a third L-type VGCC blocker, diltiazem, increased Cch1-Mid1 activity. Diltiazem did not increase $\mathrm{Ca}^{2+}$ uptake in the cch1 $1 \Delta$ and mid $1 \Delta$ single mutants and the cch1 $\Delta$ mid $1 \Delta$ double mutant, indicating that the diltiazem-induced increase in $\mathrm{Ca}^{2+}$ uptake is completely dependent on Cch1Mid1. These results suggest that Cch1 is pharmacologically similar to L-type VGCCs, but the interactions between Cch1 and the L-type VGCC blockers are more complicated than expected.

\section{INTRODUCTION}

Mammalian voltage-gated $\mathrm{Ca}^{2+}$ channels (VGCCs) are classified electrophysiologically into five classes on the basis of $\mathrm{Ca}^{2+}$ currents: L-, P/Q-, N-, R- and T-types (Catterall, 2000; Yamakage \& Namiki, 2002). All but one class (T-type) of VGCCs is inhibited by specific blockers, and these blockers are frequently used to classify VGCCs of interest. VGCCs are composed of four or five subunits: $\alpha_{1}, \alpha_{2} / \delta, \beta$ and $\gamma ; \alpha_{1}$ is the most prominent subunit, and is responsible for $\mathrm{Ca}^{2+}$ permeation, $\mathrm{Ca}^{2+}$ selectivity and voltage sensing (Catterall, 2000). The structure of the $\alpha_{1}$ subunit consists of four homologous domains (termed IIV), and each domain contains six transmembrane segments (termed S1-S6), and a membrane-associated loop (termed the pore loop or P-loop) between S5 and S6 (see Fig. 1). The P-loop has a motif, T-X-E/D-X-W,

†These authors contributed equally to this work.

Abbreviations: BTZ, benzothiazepine; DHP, dihydropyridine; PAA, phenylalkylamine; TEA, tetraethylammonium; TTX, tetrodotoxin; VGCC, voltage-gated $\mathrm{Ca}^{2+}$ channel. responsible for $\mathrm{Ca}^{2+}$ selectivity, and the S5-P-S6 region forms the pore domain. The S4 segment contains several positively charged amino acid residues, each of which is followed by two hydrophobic residues; and the segment acts as a voltage sensor.

The yeast Saccharomyces cerevisiae has one orthologue, termed Cch1, of the pore-forming $\alpha_{1}$ subunit of mammalian VGCCs (Fischer et al., 1997; Paidhungat \& Garrett, 1997). Although the organization of domains and transmembrane segments of Cch1 is similar to those of $\alpha_{1}$ subunits, overall amino acid sequence identity between Cch1 and $\alpha_{1}$ subunits is low: e.g. $24 \%$ for Cch1 versus an L-type mammalian VGCC (Paidhungat \& Garrett, 1997). It is noteworthy that one of the four S4 segments of Cch1 lacks most of the positively charged residues crucial for voltage sensing. In addition, each of the remaining three S4 segments of Cch1 has four positively charged residues, while most mammalian S4 segments have five positively charged residues. Therefore, from a structural viewpoint, it is uncertain whether Cch1 functions in response to changes in membrane potential. Cch1 constitutes a high-affinity 


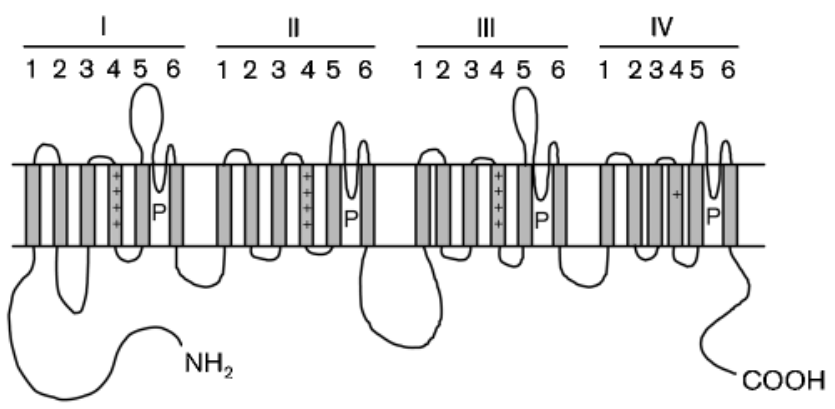

Fig. 1. Predicted membrane topology of Cch1, a homologue of animal VGCC $\alpha_{1}$ subunits. I-IV, putative domains; $1-6$, putative transmembrane segments (S1-S6); $\mathrm{P}$, putative pore loop located between the S5 and S6 segments. In the P-loop, there is a sequence homologous to the consensus $T-X-E / D-X-W$ motif, in which $\mathrm{E}$ or $\mathrm{D}$ participates in $\mathrm{Ca}^{2+}$ selectivity in animal VGCC $\alpha_{1}$ subunits. The P-loops of domains II, III and IV of Cch1 contain E, but the P-loop of domain I has N instead of E or D. + (located in the S4 segment) represents a positively charged amino acid residue $\mathrm{R}$ or $\mathrm{K}$ that serves for voltage sensing in animal VGCC $\alpha_{1}$ subunits. Cch 1 is composed of 2039 aa residues.

$\mathrm{Ca}^{2+}$-influx system with another protein, Mid1 (Muller et al., 2001). Mid1 does not have any structural homologues in higher eukaryotes, but has a stretch-activated $\mathrm{Ca}^{2+}$ channel activity when expressed in mammalian cultured cells (Kanzaki et al., 1999). Mutant cells lacking either CCH1 or MID1, or both, show the same phenotypes: low $\mathrm{Ca}^{2+}$-uptake activity, and mating-pheromone-induced death (Iida et al., 1994; Fischer et al., 1997; Paidhungat \& Garrett, 1997; Muller et al., 2001; Iida et al., 2004). The molecular nature of a high-affinity $\mathrm{Ca}^{2+}$-influx system composed of Cch1 and Mid1 is unknown. In this paper, we characterize the kinetic property of a putative Cch1-Mid1 $\mathrm{Ca}^{2+}$ channel, and present experimental evidence to suggest that yeast Cch1 is pharmacologically similar to L-type VGCCs.

\section{METHODS}

Yeast strains and plasmids. Yeast strains and plasmids used in this study are listed in Table 1.

Media. Low-Ca ${ }^{2+}$ medium SD.Ca100 containing $100 \mu \mathrm{M} \mathrm{CaCl}$ as the sole $\mathrm{Ca}^{2+}$ source, and SD-Ca medium containing no $\mathrm{CaCl}_{2}$, were prepared as described previously (Iida et al., 1990).

Blockers and agonist. Stock solutions of the following compounds were prepared as follows: $50 \mathrm{mM}$ nifedipine (in DMSO; SigmaAldrich Japan, cat. no. N7634), $100 \mathrm{mM}$ verapamil hydrochloride (in $\mathrm{H}_{2} \mathrm{O}$; Wako Jyunyaku, 222-00781), $100 \mathrm{mM} \mathrm{(+)-cis-diltiazem}$ hydrochloride (in SD.Ca100 medium; Sigma-Aldrich Japan, D2521), $25 \mathrm{mM}$ (S)-(-)-Bay K8644 (in DMSO; Sigma-Aldrich Japan, B133), $50 \mathrm{mM}$ amiloride hydrochloride hydrate (in DMSO; Sigma-Aldrich Japan; A7410), $10 \mu \mathrm{M} \omega$-agatoxin IVA (in $\mathrm{H}_{2} \mathrm{O}$; Sigma-Aldrich Japan, A6719), $100 \mu \mathrm{M} \omega$-conotoxin GIVA (in $\mathrm{H}_{2} \mathrm{O}$;
Table 1. Yeast strains and plasmids used in this study

\begin{tabular}{|c|c|c|}
\hline $\begin{array}{l}\text { Strain or } \\
\text { plasmid }\end{array}$ & Genotype & Source \\
\hline \multicolumn{3}{|l|}{ Strains } \\
\hline H207 & $\begin{array}{l}\text { MATa his3- } \Delta 1 \text { leu2-3, } \\
112 \text { trp1-289 ura3-52 sst1-2 }\end{array}$ & $\begin{array}{l}\text { Iida et al. } \\
\text { (1994) }\end{array}$ \\
\hline H315 & $\begin{array}{l}\operatorname{cch} 1 \Delta:: \text { TRP1 mid1- } \triangle 5:: H I S 3 \\
\text { in } \mathrm{H} 207\end{array}$ & $\begin{array}{l}\text { Iida et al. } \\
(2004)\end{array}$ \\
\hline \multicolumn{3}{|l|}{ Plasmids } \\
\hline pBCT-ССН1H & $\begin{array}{c}\mathrm{Ap}^{\mathrm{R}} \text { ARS1 CEN4 LEU2 } \\
\text { TDH3 } \mathrm{p}^{*}-\mathrm{CCH} 1 \mathrm{H}\end{array}$ & $\begin{array}{l}\text { Iida et al. } \\
(2007)\end{array}$ \\
\hline pBC111 & $\mathrm{Ap}^{\mathrm{R}}$ ARS1 CEN4 LEU2 & $\begin{array}{l}\text { Iida et al. } \\
\text { (2007) }\end{array}$ \\
\hline YCpT-MID1 & $\begin{array}{c}\mathrm{Ap}^{\mathrm{R}} \text { ARS1 CEN4 URA3 } \\
\text { TDH3 } \mathrm{p}^{*}-\text { MID1 }\end{array}$ & This study \\
\hline YCplac33 & $\mathrm{Ap}^{\mathrm{R}}$ ARS1 CEN4 URA3 & $\begin{array}{c}\text { Gietz \& } \\
\text { Sugino } \\
(1988)\end{array}$ \\
\hline
\end{tabular}

${ }^{*}$ TDH3p, promoter of the glyceraldehyde-3-phosphate dehydrogenase 3 gene.

Sigma-Aldrich Japan, C9915), $20 \mu \mathrm{M}$ SNX-482 (in $\mathrm{H}_{2} \mathrm{O}$; SigmaAldrich Japan, S1818), $10 \mathrm{mM}$ tetrodotoxin (TTX; in $10 \mathrm{mM}$ phosphate buffer, pH 7.0; Wako Jyunyaku, 207-15901), and $10 \mathrm{M}$ tetraethylammonium (TEA) chloride (in $\mathrm{H}_{2} \mathrm{O}$; Sigma-Aldrich Japan, T2265).

$\mathrm{Ca}^{2+}$-accumulation assay. Exponentially growing cultures (approx. $2 \times 10^{6}$ cells ml $^{-1}$ ) of yeast strains were incubated for $2 \mathrm{~h}$ at $30{ }^{\circ} \mathrm{C}$ with ${ }^{45} \mathrm{CaCl}_{2}$ (PerkinElmer Japan; $185 \mathrm{kBq} \mathrm{ml}^{-1} ; 1.81 \mathrm{kBq} \mathrm{nmol}^{-1}$ ) with or without an appropriate blocker or agonist, and an aliquot (100 $\mu \mathrm{l}$; duplicate) was taken, filtered on a Millipore filter (type HA; $0.45 \mu \mathrm{m}$ ) presoaked in $5 \mathrm{mM} \mathrm{CaCl}_{2}$, and washed five times with $5 \mathrm{ml}$ $5 \mathrm{mM} \mathrm{CaCl}_{2}$. Radioactivity retained on the filter was counted with the scintillation cocktail ReadyProtein (Beckman Coulter K.K.) in a liquid scintillation counter (Beckman Coulter K.K.).

Determination of viability. The method described by Iida et al. (1990) was followed. Aliquots $(100 \mu \mathrm{l})$ of cultures (approx. $2 \times 10^{6}$ cells $\mathrm{ml}^{-1}$; at $30{ }^{\circ} \mathrm{C}$ ) were taken and mixed with an equal volume of a solution containing $0.01 \%(\mathrm{w} / \mathrm{v})$ methylene blue and $2 \%(\mathrm{w} / \mathrm{v})$ sodium citrate. The mixture was sonicated briefly with a Sonifier (Branson model W-200P) to dissociate cell clumps. The number of methylene-blue-negative (viable) and -positive (non-viable) cells was determined by using a differential interference contrast microscope (Olympus model BX50). Viability was expressed as the percentage of the methylene-blue-negative cells in the total number of cells.

Statistics. Data are given as means \pm SD. Statistical comparisons were made with Student's $t$ test.

\section{RESULTS}

\section{Kinetic characterization of Cch1-Mid1}

Molecular cloning of the $\mathrm{CCH} 1$ gene has been unsuccessful for more than a decade since the discovery of the gene in 


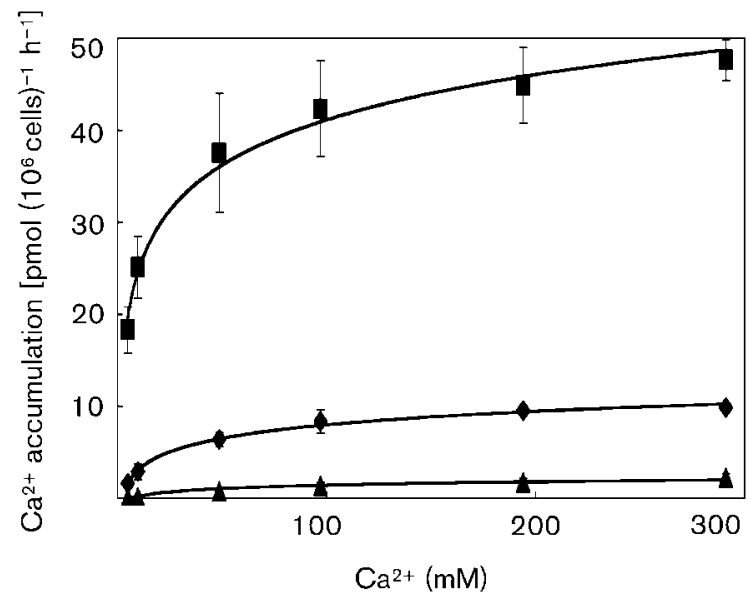

Fig. 2. Michaelis-Menten plot of $\mathrm{Ca}^{2+}$-accumulation rate versus $\mathrm{CaCl}_{2}$ concentration. Exponentially growing cells cultured in SD.Ca100 medium were harvested, washed twice with SD-Ca medium, and resuspended in SD-Ca medium containing varying concentrations $(4.85,9.7,48.5,97,194$ and $291 \mu \mathrm{M})$ of ${ }^{45} \mathrm{CaCl}_{2}$ $\left(1.81 \mathrm{kBq} \mathrm{nmol}^{-1}\right)$. The cell suspension was incubated at $30{ }^{\circ} \mathrm{C}$, with shaking. The $\mathrm{Ca}^{2+}$-accumulation rate was determined for the initial $2 \mathrm{~h}$ after the start of the incubation, as described in Methods. The data were fitted by nonlinear regression of Michaelis-Menten curves. The mean of three independent experiments $( \pm S D)$ is shown for each point. $\mathbf{a}$, CCH1ox MID1ox cells (strain $\mathrm{H} 207$ bearing pBCT-CCH1H and YCpT-MID1); , CCH1-MID1 cells (strain $\mathrm{H} 207$ bearing empty vectors pBC111 and YCplac33); $\boldsymbol{\Delta}$, cch1 $1 \Delta$ mid $1 \Delta$ cells (strain $\mathrm{H} 315$ bearing empty vectors pBC111 and YCplac33).

the S. cerevisiae genome (Paidhungat \& Garrett, 1997), but we have recently succeeded in cloning it, using a plasmid whose copy number is kept low in Escherichia coli (Iida et al., 2007). In the present study, we used the cloned gene to examine the in vivo properties of Cch1 produced from a strong promoter, TDH3p, on the plasmid pBC111 (Table $1)$. Western blotting has shown that the resulting plasmid pBCT-CCH1H ensures more than a 50 -fold overproduction of Cch1 (Iida et al., 2007). Since Cch1 requires Mid1 to function as a $\mathrm{Ca}^{2+}$-influx system (Fischer et al., 1997; Paidhungat \& Garrett, 1997; Iida et al., 2004; Muller et al., 2001), Mid1 was also designed to be produced from the same promoter on a different plasmid, YCplac33 (Table 1). Again, the plasmid thus constructed, YCpT-MID1, ensured more than 50-fold overproduction of Mid1 (data not shown). The resulting co-transformant which overexpresses both Cch1 and Mid1 (designated CCHlox MIDlox) was used to assess the properties of the putative Cch1-Mid1 $\mathrm{Ca}^{2+}$ channel. This co-overexpression system has the advantage of reducing the perturbation effect caused by unidentified $\mathrm{Ca}^{2+}$-influx systems of $S$. cerevisiae cells on $\mathrm{Ca}^{2+}$ permeation through Cch1-Mid1.

Using cells of CCH1ox MIDlox and the control strains, we first estimated the affinity for $\mathrm{Ca}^{2+}\left(K_{\mathrm{m}}\right)$, and the maximum
Table 2. $K_{\mathrm{m}}$ and $V_{\max }$ of various strains with altered copy numbers of $\mathrm{CCH} 1$ and MID1

The results presented here are mean $( \pm \mathrm{SD})$ values based on the Hanes-Woolf plots (Segel, 1976) of the data in Fig. 2.

\begin{tabular}{|lccc|}
\hline Genotype & $\boldsymbol{K}_{\mathbf{m}}(\boldsymbol{\mu} \mathbf{M})$ & $\begin{array}{c}\boldsymbol{V}_{\max }\left[\mathbf{p m o l}\left(\mathbf{1 0}^{\mathbf{6}} \text { cells }\right)^{-\mathbf{1}}\right. \\
\left.\mathbf{h}^{\mathbf{- 1}}\right]\end{array}$ & $\begin{array}{c}\boldsymbol{V}_{\mathbf{m a x}} / \\
\boldsymbol{K}_{\mathbf{m}}\end{array}$ \\
\hline CCH10x MID10x & $12 \pm 6$ & $49 \pm 3$ & 4.1 \\
CCH1-MID1 & $31 \pm 5$ & $11 \pm 0$ & 0.35 \\
cch1D mid1D & $290 \pm 53$ & $4 \pm 1$ & 0.014 \\
\hline
\end{tabular}

$\mathrm{Ca}^{2+}$-accumulation rate $\left(V_{\max }\right)$ of the putative Cch1-Mid1 channel. To do this, the cells were grown in SD.Ca100, which discloses the $\mathrm{Ca}^{2+}$-uptake activity of the putative CchlMid1 channel (Muller et al., 2001). $\mathrm{Ca}^{2+}$-accumulation assays were conducted at $30{ }^{\circ} \mathrm{C}$ for $2 \mathrm{~h}$, which was within the linear range for the cells assayed. The concentration of ${ }^{45} \mathrm{CaCl}_{2}$ was varied within single experiments, and $\mathrm{Ca}^{2+}$ accumulation in the cells was measured. As shown in Fig. 2, CCHlox MIDlox, CCH1-MID1 (wild-type) and cch1 1 mid1s cells (lacking both Cch1 and Mid1) displayed Michaelis-Menten kinetics. Table 2 shows the apparent $K_{\mathrm{m}}$ and $V_{\max }$ values deduced from the Hanes-Woolf plots for each strain. The $K_{\mathrm{m}}$ value of $C C H 1$ lox MIDlox $(12 \mu \mathrm{M})$ was approximately 2.6-fold lower than that of CCH1-MID1 $(31 \mu \mathrm{M})$, and 24 -fold lower than that of cch1s mid1s $(290 \mu \mathrm{M})$. The $V_{\max } / K_{\mathrm{m}}$ ratio, which measures the efficiency of $\mathrm{Ca}^{2+}$-channel function, and thus can be used to compare the channel function of different strains, was approximately 12 times greater in CCH1ox MIDlox than in CCH1-MID1, and 290 times greater in CCHlox MIDlox than in $\operatorname{cch} 1 \Delta$ mid1 $1 \Delta$. Therefore, it was concluded that the contribution of putative $\mathrm{Ca}^{2+}$ channels and/or transporters other than Cch1-Mid1 was negligible in CCHlox MIDlox cells under the conditions tested.

\section{Sensitivity of Cch1-Mid1 to ion-channel blockers}

To address the question of whether Cch1 is a functional homologue of mammalian VGCCs, we employed a pharmacological approach using channel blockers typical of L-, P/Q-, N-, R- or T-types of VGCCs. Since the yeast cell wall is known to provide a barrier that inhibits reagents accessing the plasma membrane (Schindler \& Davies, 1975; Gorenstein et al., 1978), the channel blockers were applied in concentrations that were almost at the upper limit of their solubility in SD.Ca100 medium. CCHlox MIDlox cells were grown overnight to exponential growth phase in SD.Ca100 medium, and further incubated for $2 \mathrm{~h}$ with one of the $\mathrm{Ca}^{2+}$-channel blockers and ${ }^{45} \mathrm{CaCl}_{2}$, and then $\mathrm{Ca}^{2+}$ accumulation was measured. As shown in Fig. 3, among the $\mathrm{Ca}^{2+}$-channel blockers tested, $200 \mu \mathrm{M}$ nifedipine (L-type) and $1 \mathrm{mM}$ verapamil (L-type) blocked $\mathrm{Ca}^{2+}$ accumulation to levels of $55 \%$ and $71 \%$, respectively, while $\omega$-agatoxin IVA (P/Q-type), $\omega$-conotoxin GIVA (Ntype), SNX-482 (R-type) and amiloride (T-type) did not 


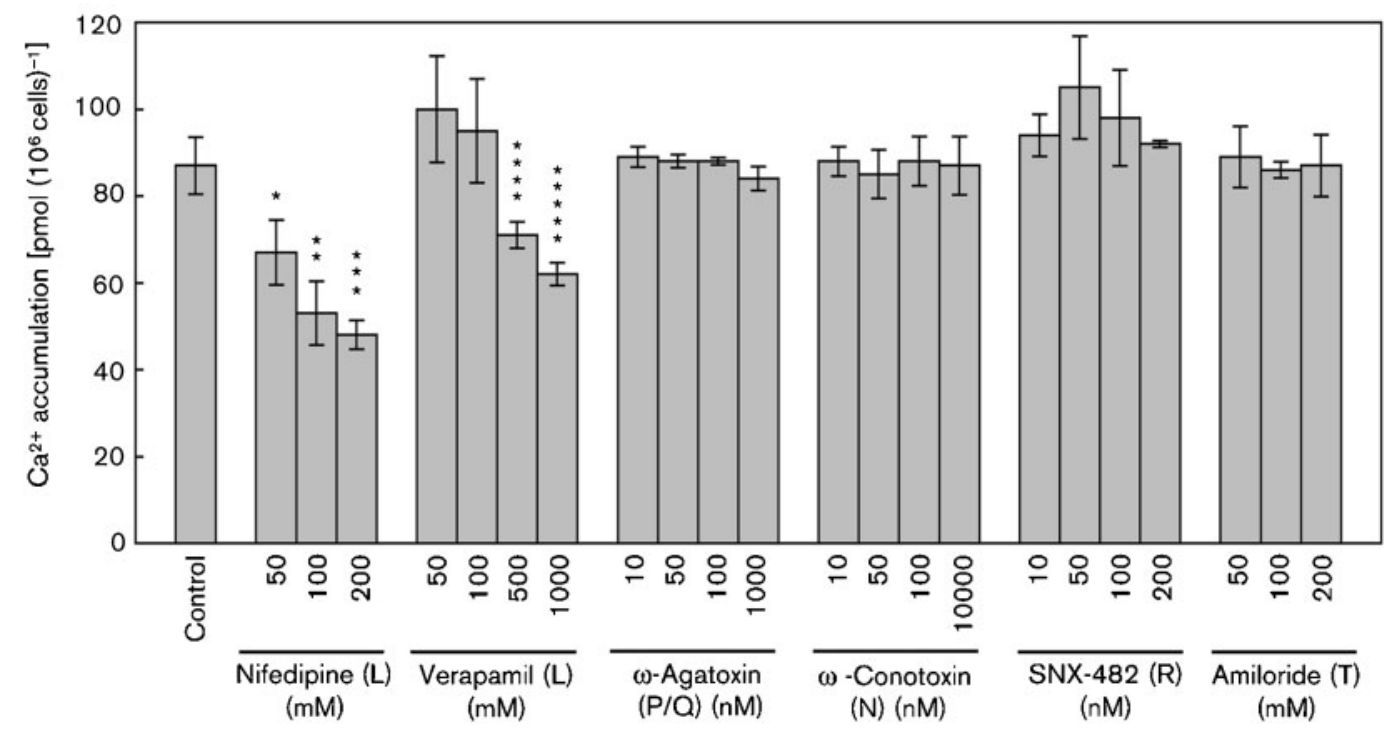

Fig. 3. Effect of VGCC blockers on Cch1 activity. Exponentially growing CCH1ox MID1ox cells grown in SD.Ca100 medium at $30{ }^{\circ} \mathrm{C}$ were incubated for $2 \mathrm{~h}$ with $100 \mu \mathrm{M}^{45} \mathrm{CaCl}_{2}\left(185 \mathrm{kBq} \mathrm{ml}^{-1} ; 1.81 \mathrm{kBq} \mathrm{nmol}^{-1}\right)$ and an appropriate blocker, and $\mathrm{Ca}^{2+}$ accumulation was determined as described in Methods. The mean of three independent experiments ( \pm SD) is shown for each point. L, P/Q, N, R and T represent the types of VGCC based upon $\mathrm{Ca}^{2+}$ current. $P$ versus control cells: ${ }^{*} P=0.00369$, ${ }^{\star \star} P=0.0103,{ }^{\star \star \star} P=0.00008,{ }^{\star \star \star \star} P=0.0036,{ }^{\star \star \star \star \star} P=0.0010$.

affect $\mathrm{Ca}^{2+}$ accumulation, even at concentrations near their solubility limit in SD.Ca100 medium. Those blockers did not affect cell viability during the course of the experiments at any concentration used (data not shown). Based on the data presented in Fig. 3, the $K_{\mathrm{i}}$ values of nifedipine and verapamil on Cch1 were estimated from Dixon plots (Segel, 1976) to be 248 and $1750 \mu \mathrm{M}$, respectively (Table 3 ). These values were much higher than those for nifedipine and verapamil on mammalian VGCC $\alpha_{1}$ subunits (Table 3 ).

Surprisingly, the third L-type blocker diltiazem enhanced $\mathrm{Ca}^{2+}$ accumulation, depending upon its concentration tested, although measurement errors were large (Fig. 4a). At the highest concentration tested $(12 \mathrm{mM})$, diltiazem enhanced $\mathrm{Ca}^{2+}$ accumulation 1.8 -fold. At the same

Table 3. $K_{\mathrm{i}}$ values for nifedipine and verapamil on Cch1

The values were estimated based on the Dixon plot for noncompetitive blockers (Segel, 1976). Examples of $K_{\mathrm{i}}$ values for the blockers on mammalian VGCC $\alpha_{1}$ subunits are also shown.

\begin{tabular}{|lcc|}
\hline & \multicolumn{2}{c|}{$\boldsymbol{K}_{\mathbf{i}}(\boldsymbol{\mu M})$} \\
\cline { 2 - 3 } & Nifedipine & Verapamil \\
\hline Cch1 & 248 & 1750 \\
Mammalian $\alpha_{1}$ subunit & $0.0156^{*}$ & $0.90 \dagger$ \\
\hline
\end{tabular}

${ }^{*}$ Rat cardiac L-type VGCC (Morel et al., 1998).

$\dagger$ Guinea pig ileal myocyte L-type VGCC (Hashimoto et al., 2006). concentration, this compound resulted in a decrease in cell viability to $68 \%$ (Fig. $4 \mathrm{~b}$ ). Microscopic observation indicated that diltiazem-treated cells were morphologically indistinguishable from untreated cells, suggesting that the increase in $\mathrm{Ca}^{2+}$ accumulation was not due to cell deterioration.

To examine whether the effects of diltiazem observed were mediated through Cch1-Mid1, $\mathrm{Ca}^{2+}$ accumulation and viability were measured for this compound in $\operatorname{cch} 1 \Delta$

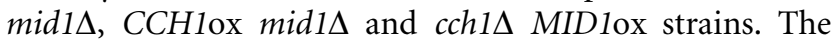
results showed that $\mathrm{Ca}^{2+}$ accumulation was not increased by diltiazem in the three strains (Fig. 4a), indicating that the diltiazem-induced increase in $\mathrm{Ca}^{2+}$ accumulation in CCH1ox MIDlox cells was mediated through Cch1-Mid1. Viability assays indicated that this compound significantly decreased the viability of $c$ ch $1 \Delta$ midl $1 \Delta$ cells to $82 \%$ at $12 \mathrm{mM}$ (Fig. 4b). This observation suggests that the decrease in the viability of CCH1ox MIDlox cells cannot be ascribed solely to the increase in $\mathrm{Ca}^{2+}$ accumulation which potentially disturbs $\mathrm{Ca}^{2+}$ homeostasis.

The VGCC agonist $(S)-(-)$-Bay K8644 $(5-100 \mu \mathrm{M})$ did not affect $\mathrm{Ca}^{2+}$ accumulation (data not shown). Since the secondary structure of VGCC $\alpha_{1}$ subunits and Cch1 is similar to that of $\mathrm{Na}^{+}$channels and six-transmembrane $\mathrm{K}^{+}$channels (Catterall, 1995), we examined the effect of the $\mathrm{Na}^{+}$-channel blocker TTX, and the $\mathrm{K}^{+}$-channel blocker TEA, on $\mathrm{Ca}^{2+}$ accumulation, and found that the blockers had no effect on $\mathrm{Ca}^{2+}$ accumulation (1010000 nM TTX; 1-100 mM TEA) (data not shown). 

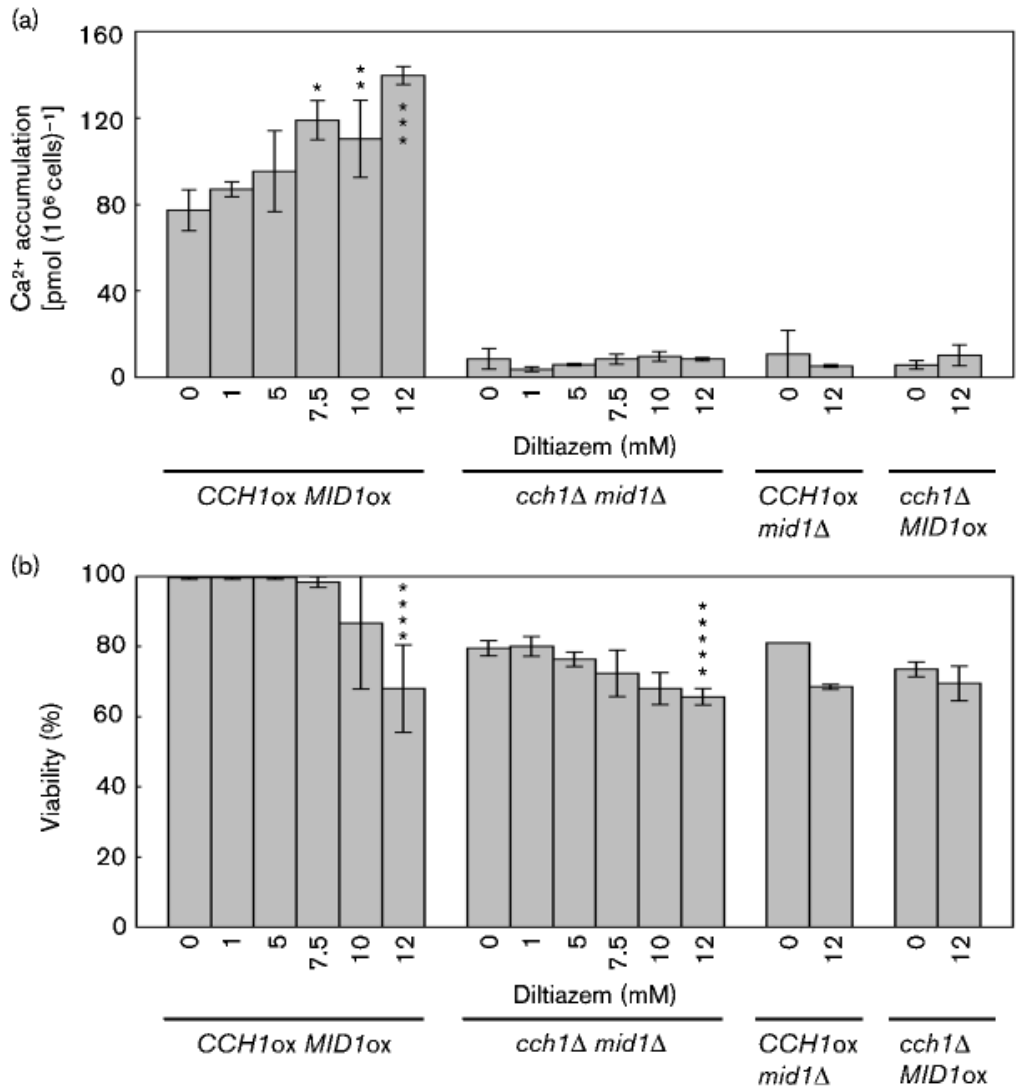

Fig. 4. Effect of the L-type VGCC blocker diltiazem on Cch1 activity (a) and cell viability (b). The experimental conditions used here were the same as those described in the legend to Fig. 3. Cell viability was determined as described in Methods. The mean of three independent experiments $( \pm S D)$ is shown for each measurement. The cch $1 \Delta$ mid1 $1 \Delta$ strain was $\mathrm{H} 315$ bearing empty vectors $\mathrm{pBC} 111$ and YCplac33. The CCH1ox mid1A strain was $\mathrm{H} 315$ bearing $\mathrm{pBCT}-\mathrm{CCH} 1 \mathrm{H}$ and YCplac33. The cch1D MID1ox strain was H315 bearing $\mathrm{pBC} 111$ and YCpT-MID1. $P$ versus control cells: ${ }^{\star} P=0.005,{ }^{\star \star} P=0.0478$, ${ }^{\star \star *} P=0.0005,{ }^{\star * \star \star} P=0.0118,{ }^{\star \star * \star *} P=0.0068$.

\section{DISCUSSION}

The results in the present study, especially those for the effect of nifedipine and verapamil, suggest that Cch1 is pharmacologically similar to L-type VGCCs. However, this suggestion is not clear-cut because another L-type blocker, diltiazem, enhanced $\mathrm{Ca}^{2+}$ accumulation unexpectedly (Fig. 4a). A possible explanation for this unexpected observation is that diltiazem may specifically bind to Cch1 to activate $\mathrm{Ca}^{2+}$ entry, instead of blocking it. The second possibility is that diltiazem, at high concentrations, may be a stress for yeast cells, and that it indirectly stimulates the $\mathrm{Ca}^{2+}$. channel activity of Cch1, because, at $12 \mathrm{mM}$, this compound kills about $32 \%$ of CCH1ox MIDlox cells and $18 \%$ of $c$ ch $1 \Delta$ mid $1 \Delta$ cells (Fig. $4 \mathrm{~b}$ ). Several stresses, including endoplasmic reticulum stress caused by tunicamycin (an inhibitor of $\mathrm{N}$-glycosylation) or dithiothreitol (an inhibitor of disulfide bond formation), hyperosmotic stress and alkaline stress, have been reported to activate the Cch1-Mid1 channel (Bonilla et al., 2002; Matsumoto et al., 2002; Viladevall et al., 2004). The third possibility is that diltiazem at high concentrations $(7.5-12 \mathrm{mM})$ causes nonspecific fluxes of ions without activating Cch1. It has been reported that diltiazem increases the cation and anion permeability of biological membranes, such as bovine photoreceptor membranes, at high concentrations (12.5$200 \mu \mathrm{M}$; Caretta et al., 1991). However, as mentioned above, our study showed that diltiazem, even at $12 \mathrm{mM}$, did not increase $\mathrm{Ca}^{2+}$ accumulation in $\operatorname{cch} 1 \Delta$ mid1s cells (Fig. 4a), indicating that the diltiazem-induced increase in $\mathrm{Ca}^{2+}$ accumulation depends on the Cch1-Mid1 channel. Therefore, the third possibility seems unlikely.

It should be noted that the half-blocking concentrations of organic $\mathrm{Ca}^{2+}$-channel blockers, including nifedipine and verapamil, are in the $20 \mathrm{nM}$ to $50 \mu \mathrm{M}$ range, depending upon the type of vertebrate cells (Triggle, 1990; Hille, 1992; Catterall et al., 2005). These concentrations are much lower than those used for S. cerevisiae cells in this study. One reason for the necessity of high concentrations of the blockers could be the presence of the cell wall in $S$. cerevisiae cells. In the case of actinomycin $\mathrm{D}$, which binds to DNA to inhibit RNA synthesis, it has been reported that spheroplasts lacking the cell wall are more sensitive to this antibiotic than intact cells of S. cerevisiae (Gorenstein et al., 1978). Since lytic enzymes that degrade the cell wall to generate spheroplasts contain proteases as well as endoglucanases (Scott \& Schekman, 1980), proteins protruding from the plasma membrane, including $\mathrm{Ca}^{2+}$ channels, would be damaged during spheroplast preparation. Therefore, careful examination is necessary to assess $\mathrm{Ca}^{2+}$-uptake activity in spheroplasts.

Another reason for the need for high concentrations of nifedipine and verapamil (Fig. 3) could be a difference in the binding sites of these L-type blockers, in addition to the 


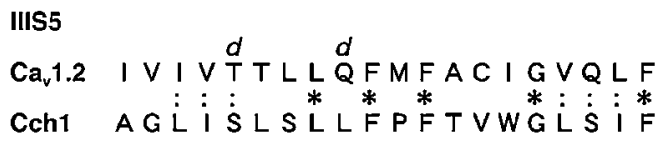

Identical, 25\%; Similar, 30\%; Total 55\%

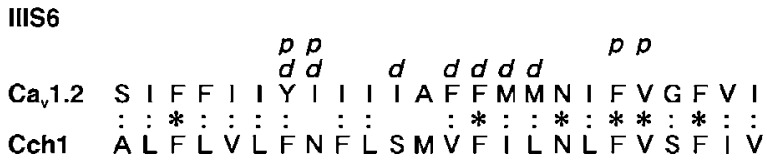

Identical, 25\%; Similar, 63\%; Total, $88 \%$

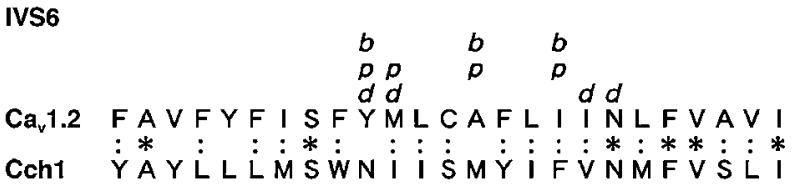

Identical, $24 \%$; Similar $60 \%$; Total, $84 \%$

Fig. 5. Amino acid sequences of the IIIS5, IIIS6 and IVS6 segments of a mammalian VGCC and Cch1. The upper sequences (written by Mitterdorfer et al., 1998) are according to a rat brain $\mathrm{Ca}_{v} 1.2 \alpha_{1}$ subunit (rbCll) (GenBank accession number M67515) and the lower sequences Cch1 (GenBank accession number Z73002). Italicized lower-case letters indicate DHP (d), PAA $(p)$, and BTZ $(b)$. Nifedipine is a member of the DHP group, verapamil is a member of the PAA group, and diltiazem is a member of the BTZ group. The position of these letters on the upper sequences shows the amino acid residues that contribute to blocker binding, as summarized for mammalian VGCCs (Mitterdorfer et al., 1998). Asterisks indicate identical amino acids, and colons indicate conserved amino acid substitutions determined according to the CLUSTAL W program (Chenna et al., 2003).

presence of the cell wall. Although the three L-type blockers used in this study are classified into the same type, their binding sites are not completely identical (Mitterdorfer et al., 1998; Striessnig, 1999). Nifedipine, verapamil and diltiazem are members of the chemically unrelated classes of L-type blockers dihydropyridines (DHPs), phenylalkylamines (PAAs) and benzothiazepines (BTZs), respectively. As shown in Fig. 5, the three classes bind to two or three of the transmembrane segments IIIS5, IIIS6 and IVS6 in mammalian L-type VGCCs, and the binding of each class is unique in each segment. Alignment of the corresponding transmembrane segments of Cch1 with a mammalian VGCC shows that the binding sites of Cch1 for the three classes are limited: there is no identical amino acid residue in IIIS5; there is one for DHPs, and two for PAAs in IIIS6; and one for DHPs in IVS6 (Fig. 5). This limitation may account for the low affinities of nifedipine and verapamil to Cch1.

A BLAST search (http://www.ncbi.nlm.nih.gov/BLAST/) with the amino acid sequence of the $S$. cerevisiae Cch1 found homologous proteins for over 30 fungal species, including pathogenic fungi. Modulation of fungal Cch1 function has been suggested to be useful in the development of cures for fungal diseases in humans caused by Candida albicans (Bonilla et al., 2002), Candida glabrata (Kaur et al., 2004), Cryptococcus neoformans (Liu et al., 2006) and Trichophyton rubrum (Yu et al., 2007), and for those in plants caused by Magnaporthe grisea (Zelter et al., 2004). This suggestion should facilitate further study on $\mathrm{Cch} 1$ and related $\mathrm{Ca}^{2+}$ signalling mechanisms, and expand it to other pathogenic fungi. Our study with diltiazem indicates that when assessing the effect of a blocker of interest on any fungal species, one should always measure $\mathrm{Ca}^{2+}$ accumulation or influx in terms of $\mathrm{Ca}^{2+}$ signalling and curing the fungal disease.

\section{ACKNOWLEDGEMENTS}

We thank Dr Masami Yoshino for his comment on channel blockers, and Ms Yumiko Higashi for her secretarial work. This work was supported by a Grant-in-Aid for Scientific Research on Priority Areas (No. 15031212 to H. I), a Grant-in-Aid for Scientific Research B (No. 16370072 to H. I.), and a Grant-in-Aid for Scientific Research C (No. 20570158 to K. I.) from the Ministry of Education, Culture, Sports, Science and Technology in Japan, and a grant for the Frontiers of Membrane Protein Research (the Joint Project between the Institute for Protein Research, Osaka University and Okazaki Institute for Integrative Bioscience; to H. I.).

\section{REFERENCES}

Bonilla, M., Nastase, K. K. \& Cunningham, K. W. (2002). Essential role of calcineurin in response to endoplasmic reticulum stress. EMBO J 21, 2343-2353.

Caretta, A., Sorbi, R. T., Stein, P. J. \& Tirindelli, R. (1991). Diltiazem at high concentration increases the ionic permeability of biological membranes. J Membr Biol 122, 203-213.

Catterall, W. A. (1995). Structure and function of voltage-gated ion channels. Annu Rev Biochem 64, 493-531.

Catterall, W. A. (2000). Structure and regulation of voltage-gated $\mathrm{Ca}^{2+}$ channels. Annu Rev Cell Dev Biol 16, 521-555.

Catterall, W. A., Perez-Reyes, E., Snutch, T. P. \& Striessnig, J. (2005). International union of pharmacology. XLVIII. Nomenclature and structure-function relationships of voltage-gated calcium channels. Pharmacol Rev 57, 411-425.

Chenna, R., Sugawara, H., Koike, T., Lopez, R., Gibson, T. J., Higgins, D. G. \& Thompson, J. D. (2003). Multiple sequence alignment with the CLUSTAL series of programs. Nucleic Acids Res 31, 3497-3500.

Fischer, M., Schnell, N., Chattaway, J., Davies, P., Dixon, G. \& Sanders, D. (1997). The Saccharomyces cerevisiae CCH1 gene is involved in calcium influx and mating. FEBS Lett 419, 259-262.

Gietz, R. D. \& Sugino, A. (1988). New yeast-Escherichia coli shuttle vectors constructed with in vitro mutagenized yeast genes lacking sixbase pair restriction sites. Gene 74, 527-534.

Gorenstein, C., Atkinson, K. D. \& Falke, E. V. (1978). Isolation and characterization of an actinomycin D-senstitive mutant of Saccharomyces cerevisiae. J Bacteriol 136, 142-147.

Hashimoto, M., Teramoto, N., Zhu, H.-L., Takahashi, K. \& Ito, Y. (2006). Comparative studies of AJG049, a novel $\mathrm{Ca}^{2+}$ channel antagonist, on voltage-dependent L-type $\mathrm{Ca}^{2+}$ currents in intestinal and smooth muscle. Br J Pharmacol 149, 155-162.

Hille, B. (1992). Ionic Channels of Excitable Membranes, 2nd edn. Sunderland, MA: Sinauer Associates. 
lida, H., Yagawa, Y. \& Anraku, Y. (1990). Essential role for induced $\mathrm{Ca}^{2+}$ influx followed by $\left[\mathrm{Ca}^{2+}\right]_{\mathrm{i}}$ rise in maintaining viability of yeast cells late in the mating pheromone response pathway: a study of $\left[\mathrm{Ca}^{2+}\right]_{\mathrm{i}}$ in single Saccharomyces cerevisiae cells with imaging of fura- 2 . J Biol Chem 265, 13391-13399.

lida, H., Nakamura, H., Ono, T., Okumura, M. S. \& Anraku, Y. (1994). MID1, a novel Saccharomyces cerevisiae gene encoding a plasma membrane protein, is required for $\mathrm{Ca}^{2+}$ influx and mating. Mol Cell Biol 14, 8529-8271.

lida, K., Tada, T. \& lida, H. (2004). Molecular cloning in yeast by in vivo homologous recombination of the yeast putative $\alpha_{1}$ subunit of the voltage-gated calcium channel. FEBS Lett 576, 291-296.

lida, K., Teng, T., Tada, T., Saka, A., Tamai, M., Izumi-Nakaseko, H., Adachi-Akahane, S. \& lida, H. (2007). Essential, completely conserved glycine residue in the domain III S2-S3 linker of voltage-gated calcium channel $\alpha_{1}$ subunits in yeast and mammals. J Biol Chem 282, 25659-25667.

Kanzaki, M., Nagasawa, M., Kijima, I., Sato, C., Naruse, K., Sokabe, M. \& lida, H. (1999). Molecular identification of a eukaryotic, stretchactivated nonselective cation channel. Science 285, 882-886 [report clarification in Science (2000) 288, 1347].

Kaur, R., Cataño, I. \& Cormack, B. P. (2004). Functional genomic analysis of fluconazole susceptibility in the pathogenic yeast Candida glabrata: role of calcium signaling and mitochondria. Antimicrob Agents Chemother 48, 1600-1613.

Liu, M., Du, P., Heinrich, G., Cox, G. M. \& Gelli, A. (2006). Cch1 mediates calcium entry in Cryptococcus neoformans and is essential in low-calcium environments. Eukaryot Cell 5, 1788-1796.

Matsumoto, T. K., Ellsmore, A. J., Cessna, S. G., Low, P. S., Pardo, J. M., Bressan, R. A. \& Hasegawa, P. M. (2002). An osmotically induced cytosolic $\mathrm{Ca}^{2+}$ transient activates calcineurin signaling to mediate ion homeostasis and salt tolerance of Saccharomyces cerevisiae. J Biol Chem 277, 33075-33080.

Mitterdorfer, J., Grabner, M., Kraus, R. L., Hering, S., Prinz, H., Glossmann, H. \& Striessnig, J. (1998). Molecular basis of drug interaction with L-type $\mathrm{Ca}^{2+}$ channels. J Bioenerg Biomembr 30, 319334.

Morel, N., Buryi, V., Gomez, J.-P., Christen, M.-O. \& Godfraind, T. (1998). The action of calcium channel blockers on recombinant
L-type calcium channel $\alpha_{1}$-subunits. $B r J$ Pharmacol 125, 1005 -1012 .

Muller, E. M., Locke, E. G. \& Cunningham, K. W. (2001). Differential regulation of two $\mathrm{Ca}^{2+}$ influx systems by pheromone signaling in Saccharomyces cerevisiae. Genetics 159, 1527-1538.

Paidhungat, M. \& Garrett, S. (1997). A homolog of mammalian, voltage-gated calcium channels mediates yeast pheromone-stimulated $\mathrm{Ca}^{2+}$ uptake and exacerbates the $c d c 1$ (Ts) growth defect. Mol Cell Biol 17, 6339-6347.

Schindler, D. \& Davies, J. (1975). Inhibitors of macromolecular synthesis in yeast. Methods Cell Biol 12, 17-38.

Scott, J. H. \& Schekman, R. (1980). Lyticase: endoglucanase and protease activities that act together in yeast cell lysis. J Bacteriol 142, 414-423.

Segel, I. H. (1976). Biochemical Calculations: How to Solve Mathematical Problems in General Biochemistry, 2nd edn. New York: John Wiley.

Striessnig, J. (1999). Pharmacology, structure and function of cardiac L-type $\mathrm{Ca}^{2+}$ channels. Cell Physiol Biochem 9, 242-269.

Triggle, D. J. (1990). Calcium antagonists. In Cardiovascular Pharmacology, 3rd edn, pp. 107-160. Edited by M. Antonaccio. New York: Raven Press.

Viladevall, L., Serrano, R., Ruiz, A., Domenech, G., Giraldo, J., Barceló, A. \& Ariño, J. (2004). Characterization of the calciummediated response to alkaline stress in Saccharomyces cerevisiae. J Biol Chem 279, 43614-43624.

Yamakage, M. \& Namiki, A. (2002). Calcium channels - basic aspects of their structure, function and gene encoding; anesthetic action on the channels - a review. Can J Anaesth 49, 151-164.

Yu, L., Zhang, W., Wang, L., Yang, J., Liu, T., Peng, J., Leng, W., Chen, L., Li, R. \& Jin, Q. (2007). Transcriptional profiles of the response to ketoconazole and amphotericin B in Trichophyton rubrum. Antimicrob Agents Chemother 51, 144-153.

Zelter, A., Bencina, M., Bowman, B. J., Yarden, O. \& Read, N. D. (2004). A comparative genomic analysis of the calcium signaling machinery in Neurospora crassa, Magnaporthe grisea, and Saccharomyces cerevisiae. Fungal Genet Biol 41, 827-841.

Edited by: J. M. Becker 